\title{
FAKTOR YANG BERHUBUNGAN DENGAN NIAT DAN PERILAKU SANTRI PESANTREN AL FITRAH UNTUK TERLIBAT AKTIF DALAM POSKESTREN
}

\section{Factor That Related To A Goodwill And Behavior Student Of Al Fitrah To Engage Active In Poskestren}

\author{
Faishal Farisy ${ }^{1}$, Pulung Siswantara ${ }^{2}$ \\ Departemen Promosi Kesehatan dan Ilmu Perilaku \\ Fakultas Kesehatan Masyarakat, Universitas Airlangga Surabaya \\ Email : faishalfarisy@gmail.com
}

\begin{abstract}
Poskestren is a unit of Community Based Health Efforts in the boarding school that will provide basic health services focusing on health promotion, prevention, rehabilitation (protecting, preventing, and maintaining health) to the Clean and Healthy Lifestyle Behavior (PHBs).However, poskestren had not fully utilized by the citizens in schools, especially the students.This study aims to determine the factors associated with poskestren utilization by students at the Pondok Pesantren Al Fitrah poskestren Surabaya.This research is quantitative research with cross sectional approach.A sample of 93 responden.Based on the results of a statistical analysis of 93 respondents indicated that students who have a good knowledge (60.2\%), have a good attitude (94.6\%), have a good subjective norm (74.2\%), have control behavior felt good (65.6\%), have a good intention to be actively involved in Poskestren (75.3\%) and active behavior Poskestren actively involved in both (74.2\%).Based on statistical tests using the Theory of Planned Behavior significant relationship between attitudes and behavior control on the intention and control the behavior and intentions of the behavior Value with a $P$ value $<0.05$. Based on the results above, it is advisable for Poskestren to make efforts for improving the utilization of poskestren include: providing information on the purpose, role and function poskestren, and make efforts to improve access to services to the students poskestren.
\end{abstract} Keywords: Intention and Active behavior, Poskestren, Theory of Planned Behavior 


\begin{abstract}
ABSTRAK
Poskestren adalah wujud Upaya Kesehatan Bersumberdaya Masyarakat di pondok pesantren yang memeberikan pelayanan kesehatan dasar yang difokuskan pada pelayanan promotif, preventife, rehabilitative (melindungi, mencegah memelihara kesehatan) menuju perilaku Hidup Bersih Sehat (PHBS). Namun demikian, poskestren ternyata belum sepenuhnya dimanfaatkan oleh warga yang ada di pesantren terutama para santri. Penelitian ini bertujuan untuk mengetahui faktor-faktor yang berhubungan dengan pemanfaatan poskestren oleh santri di poskestren Pondok Pesantren Al Fitrah Kota Surabaya. Penelitian ini termasuk jenis penelitian kuantitatif dengan pendekatan Cross Sectional. Sampel sebanyak 93 respnden. Berdasarkan hasil dari analisis statistik terhadap 93 responden menunjukkan bahwa santri yang mempunyai pengetahuan yang baik $(60,2 \%)$, mempunyai sikap yang baik $(94,6 \%)$, mempunyai norma subjektif yang baik (74,2\%), mempunyai kontrol perilaku yang dirasakan baik $(65,6 \%)$, mempunyai niat yang baik untuk terlibat aktif dalam Poskestren $(75,3 \%)$ dan perilaku aktif terlibat aktif dalam Poskestren baik $(74,2 \%)$. Berdasarkan uji statistic dengan menggunakan Theory of Planned Behavior terdapat hubungan yang signifikan antara sikap dan kontrol perilaku terhadap niat serta kontrol perilaku dan niat terhadap perilaku dengan nilai $\mathrm{P}$ Value $<0,05$. Berdasarkan hasil penelitian diatas, disarankan bagi Poskestren perlunya melakukan usaha-usaha untuk meningkatkan pemanfaatan poskestren berupa : memberikan informasi mengenai tujuan, peran dan fungsi poskestren, serta melakukan usaha-usaha meningkatkan akses pelayanan poskestren kepada para santri
\end{abstract}

Kata Kunci : Niat dan Perilaku aktif, Poskestren, Theory of Planned Behavior 


\section{PENDAHULUAN}

Pesantren sebagai lembaga pendidikan yang memiliki akar kuat pada masyarakat muslim Indonesia, dalam perjalanannya mampu menjaga dan mempertahankan keberadaan dirinya serta memiliki model pendidikan yang multi fungsi dan multi aspek. Santri tidak hanya diajarkan menjadi seseorang yang mengerti ilmu agama dan ilmu umum saja namun juga mendapat tempaan kepemimpinan yang alami, kemandirian, kesederhanaan, ketekunan, kebersamaan, kesetaraan, dan sikap positif lainnya. Nantinya modal inilah yang diharapkan dapat melahirkan masyarakat yang berkualitas dan mandiri. sebagai bentuk partisipasi pesantren dalam menyukseskan tujuan pembangunan nasional sekaligus berperan aktif dalam mencerdaskan bangsa sesuai yang diamanatkan oleh Undang - Undang Dasar 1945 (Amin Haedari, 2004)

Jika dilihat dari sisi kesehatan pada umumnya kondisi kesehatan di lingkungan pondok pesantren masih sangat memerlukan perhatian dari berbagai pihak terkait, baik dalam aspek akses pelayanan kesehatan, perilaku sehat maupun kesehatan lingkungannya adapun berbagai masalah kesehatan yang sering terjadi di pondok pesantren diantaranya ialah gatalgatal atau scabies, gudiken, sesak nafas, demam, batuk, pilek, influenza dan maag. Pemberdayaan masyarakat di pondok pesantren merupakan upaya agar warga pondok pesantren mengenal masalah kesehatan yang dihadapi, merencanakan dan melakukan upaya pemecahannya dengan memanfaatkan potensi setempat sesuai situasi, kondisi dan kebutuhan setempat. Dalam rangka pengkoordinasian penyelenggaraan berbagai UKBM yang ada di Pondok Pesantren maka dibentuklah UKBM yang berfungsi koordinatif yaitu Pos Kesehatan Pesantren (Poskestren).

Di indonesia pedoman tentang penyelenggaraan dan pembinaan Pos Kesehatan Pesantren (Poskestren) telah diatur dalam SK Mentri Kesehatan No.867/Menkes/SK/XI/2006 tentang Poskestren yang berisikan tentang tujuan, sasaran, fungsi dan manfaat serta pedoman tata laksana dari poskestren itu sendiri. Ditetapkannya pedoman ini adalah bertujuan untuk percepatan terwujudnya visi Indonesia Sehat dari Departemen Kesehatan yaitu "Masyarakat Yang Mandiri Untuk Hidup Sehat" dan dengan misi "Membuat Masyarakat Sehat" yang mana masyarakat dalam hal ini adalah seluruh warga pondok pesantren termasuk di dalamnya santri.

Santrimerupakan kelompok usia transisi dari masa remaja akhir menjadi dewasa awal yang lebih mandiri dalam menentukan perilaku apa yang akan dilakukan. Pada tahap ini, remaja akanlebih memikirkanrencana yang akan datang dan meningkatkanpergaulan di lingkungan serta hidup lebih mandiri (Poltekkes Depkes Jakarta I, 2010).

Berdasarkan pengambilan data awal pada santri di Pondok Pesantren Al Fitrah Surabaya dengan jumlah 93 responden didapatkan bahwa sebanyak $60,2 \%$ santri memiliki penegtahuan yang baik tentang Poskestren. santri yang tinggal di Pondok Pesantren Al Fitrah rata-rata mengikuti kegiatan Poskestren sebanyak 3-5 kali dalam seminggu

Santri sebagai agen perubahan yang membawa nilai moral dan akhlaqul karimah dan bagian dari rakyat Indonesia diharapkan memiliki kondisi dan gaya hidup yang sehat. Oleh karena itu perlu adanya faktor yang mendukung hal tersebut, yang mampu mengarahkan seorang mahasiswa untuk berperilaku menjaga kesehatannya dengan terlibat aktif dalam Poskestren. Faktor itu bisa dari diri sendiri, keluarga, teman, maupun lingkungannya.

Niat dari suatu perilaku hanya dapat muncul jika seseorang mampu memutuskan keinginannya untuk melakukan atau tidak melakukan perilaku. Ajzen (2005) menjelaskan dalam Theory of Planned Behavior bahwa faktor yang dapat mempengaruhi niat adalah sikap, norma subyektif, dan kontrol perilaku. Semakin positif sikap, norma subyektif, dan kontrol perilaku terhadap perilaku untuk makan sayur dan buah dalam memprediksi niat, 
diharapakan niat dapat menggambarkan perilakunya terlibat aktif dalam Pokestren

Buah dari niat ini nantinya akan menjadi suatu perilaku yang mana dalam Theory of Planned Behaviormenjelasakan jika kontrol perilaku dan niat adalah faktor yang berhubungan langsung dengan perilaku itu sendiri, yang mana ini berarti variabel sikap, norma subjektif dan kontrol perilaku serta niat ini nantinya yang akan membentuk perilaku untuk terlibat aktif dalam Poskestren sesuai dengan Theory of Planned Behavior yang telah dijelaskan ajzen

Tujuan umum dari penelitian adalah menganalisis faktor yang mempengaruhi niat dan perilaku dantri untukterlibat aktif dalam Poskestren berlandaskanTheory of Planned Behavior. Adapun tujuan khususnya yang pertama adalah untuk melihat kararkterisitik santri Pondok Pesantren Al Fitrah. Tujuan kedua untuk mengidentifikasi sikap, norma subyektif, kontrol perilaku dan niat serta perilaku santri untuk terlibat aktif dalam Poskestren. Ketiga adalah untuk menganalisis pengaruh sikap, norma subyektif, dan kontrol perilaku serta niat terhadap perilaku terlibat aktif dalam Poskestren.

\section{METODE PENELITIAN}

Penelitian ini merupakan penilitian Observasional analitik dengan menggunakan pendekatan kuantitatif. Berdasarkan waktu pengambilan data, penelitian ini menggunakan pendekatan cross sectional yaitu dengan pengambilan data antar variabel yang dilakukan secara bersamaan.

Populasi santri putra yang bermukim di Pondok Pesantren Al Fitrah adalah 1332 santri. Adapun sampel dalam penelitian ini mengambil dari populasi santri dengan menggunakan rumussimple random samplingmenurut Notoatmojo (1993). Sesudah perhitungan dilakukan dengan rumus terdapat sebesar 93santri Pondok Pesantren Al Fitrah yang mukim sebagai responden.

Tempat penelitian ini dilakukandi Pondok Pesantren Al Fitrah, Jl. Kedinding
Lor no.99 Surabaya. Pengambilan data pada penilitian ini dilaksanakan pada bulan april - mei 2016. Pengambilan data primer diawali dengan peneliti menjelaskan pada responden tentang penjelasan gambaran tujuan dan pelaksanaan penelitian. Sesudahresponden mengerti maka akan dilakukan pengisian dan penandatanganan lembar persetujuan (informed consent). Pengisian kuesioner dilaksanakandalam waktu kurang lebih sekitar 15 menit yang dilaksanakan asrama Pondok Pesantren Al Fitrah diluar jam efektif santri.

Variabel independen dalam penelitian ini adalah sikap, norma subyektif, kontrol perilaku dan niat untuk terlibat aktif dalam Poskestren Pondok Pesantren Al Fitrah . sementara Variabel dependen dalam penelitian ini adalah perilaku untuk terlibat aktif dalam Poskestren Pondok Pesantren Al Fitrah

Pengolahan data yang dilakukan ialah menggunakan skoring lalu dianalisis dengan tujuan untuk melihat hubungan antara sikap, norma subyektif, dan kontrol perilaku dan niat terhadap perilaku untuk terlibat aktif dalam Poskestren Pondok Pesantren Al Fitrah dengan menggunakan uji statistik chi square.

\section{HASIL PENELITIAN DAN PEMBAHASAN}

Berdasarkan hasil pengolahan data, distribusi responden dapat dilihat frekuensinya dari kategori umur dan pengetahuan. Responden dalam penelitian ini adalah Santri Putra Pondok Pesantren Al Fitrah dengan jumlah responden 93 orang. Berdasarkan kategori umur mayoritas penghuni asrama berkisar antara 16-20 tahun dengan jumlah terbanyak pada umur 18 tahun yaitu sebesar $41,9 \%$ dari total penghuni asrama

Tabel 1. Karakteristik Responden berdasarkan Umur Pondok Pesantren Al Fitrah tahun 2016

\begin{tabular}{lcc}
\hline $\begin{array}{c}\text { Umur } \\
\text { Responden }\end{array}$ & $\mathbf{N}$ & $\mathbf{\%}$ \\
\hline 16 tahun & 6 & $6,4 \%$ \\
17 tahun & 25 & $26,8 \%$
\end{tabular}




\begin{tabular}{ccc}
18 tahun & 39 & $41,9 \%$ \\
19 tahun & 20 & $31,7 \%$ \\
20 tahun & 3 & $3,2 \%$ \\
Total & $\mathbf{9 3}$ & $\mathbf{1 0 0 \%}$ \\
\hline
\end{tabular}

Berdasarkan data yang diperoleh dalam pengisian kuisioner oleh santri Pondok Pesantren Al Fitrahmenunjukkan bahwa responden mayoritas 16-20 tahun.Berdasarkan tahapan pertumbuhan individu, masa remaja dibagi menjadi tiga tahapan yakni masa remaja awal, masa remaja pertengahan, dan masa remaja akhir. Hal ini menunjukkan bahwa responden masuk dalam kriteria remaja pertengahan dan akhir yaitu dalam kategori umur 16-20 tahun. Usia 16-20 tahun merupakan kriteria remaja akhir sebelum memasuki usia dewasa. Untuk remaja akhir atau late adolescence ditandai dengan pertumbuhan biologis yang sudah melambat, tetapi masih berlangsung. Emosi, minat, konsentrasi, dan cara berpikir remaja akhir mulai stabil. Kemampuan untuk menyelesaikan masalah sudah mulai meningkat. Pada tahap ini, remaja lebih berkonsentrasi pada rencana yang akan datang serta bagaimana meningkatkan pergaulan (Poltekkes Depkes Jakarta I, 2010).

\section{Pengetahuan}

Pengetahuan santri putra Pondok Pesantren Al Fitrah mengenai Poskestren dan manfaatnya mayoritas dalam kategori baik yakni sebesar 60,2\%. Dari hasil penelitian tidak ada santri Pondok Pesantren Al Fitrah yang masuk dalam kategori pengetahuan yang kurang tentang Poskestren

Tabel 2. Distribusi Responden berdasarkan Pengetahuan Pondok Pesantren Al Fitrah tahun 2016

\begin{tabular}{lcc}
\hline \multicolumn{1}{c}{ Pengetahuan } & N & \% \\
\hline Baik & 56 & $60,2 \%$ \\
Cukup Baik & 37 & $39,8 \%$ \\
Kurang Baik & 0 & $0 \%$ \\
$\quad$ Total & $\mathbf{9 3}$ & $\mathbf{1 0 0 \%}$ \\
\hline
\end{tabular}

Berdasarkan data yang didapatkan sebanyak 37 santri masih tergolong memiliki pengetahuan yang cukup tentang Poskestren dan manfaatnya. Santri dalam hal ini juga dapat dikategorikan orang yang berpendidikan baik. Hal ini wajar jika sebagian besar memiliki pengetahuan yang baik Poskestren dan manfaatnya.

\section{Sikap Terhadap Perilaku}

Sikap terhadap perilaku dibentuk oleh keyakinan yang diperoleh dari konsekwensidalam menunjukan suatu perilaku yang bisa disebut dengan behavioral beliefs (Ajzen, 2005).Hal iniberkaitan dengan penilaian seseorang secara subyektif terdahap orang di sekitarnya dan kemampuan untuk memahami lingkungan yang ia tempati tersebut.

Distribusi responden berdasarkan sikap terhadap perilaku terlibat aktif dalam Poskestren (Attitudes toward Behavior) pada santri Pondok Pesantren Al Fitrah Surabaya dapat dilihat pada tabel 3.

Tabel 3. Distribusi Responden berdasarkan Sikap terhadap perilaku santri Pondok Pesantren Al Fitrah Surabaya Tahun 2016

\begin{tabular}{lcc}
\hline \multicolumn{1}{c}{ Sikap } & N & \% \\
\hline Baik & 88 & $94,6 \%$ \\
Cukup Baik & 5 & $5,4 \%$ \\
Kurang Baik & 0 & $0 \%$ \\
$\quad$ Total & $\mathbf{9 3}$ & $\mathbf{1 0 0 \%}$ \\
\hline
\end{tabular}

Dari tabel 3 diatas dapat dilihat jika mayoritas responden memiliki Sikap terhadap Perilaku yang sangat baik tentang terlibat aktif dalam Poskestren (94,6\%). Sikap dapat terbentuk oleh pengetahuan yang cukup terhadap suatu perilaku. Santri Pondok Pesantren Al Fitrahdengan tingkat pendidikan yang baik memungkinkan untuk memiliki sikap yang baik untuk kesehatannya juga terutama untuk terlibat aktif dalam Poskestren.

\section{Norma Subyektif Responden}

Norma subjektif dalam hal iniberhubungan dengan perasaan dan perkiraan dalamharapannyaterhadap orang yang 
berada di lingkungan sekitarnyadalam mewujudkan suatu perilaku tertentu.Subjective normdisiniditentukan oleh referentdan motivation to comply.

Distribusi responden berdasarkan norma subyektif (Subjective Norm) santri Pondok Pesantren Al Fitrah terdapat pada tabel 4.

Tabel 4. Distribusi Responden berdasarkan Norma Subyektif santri Pondok Pesantren Al Fitrah tahun 2016

\begin{tabular}{lcc}
\hline $\begin{array}{c}\text { Norma } \\
\text { Subyektif }\end{array}$ & N & \% \\
\hline Baik & 69 & $74,2 \%$ \\
Cukup Baik & 24 & $25,8 \%$ \\
Kurang Baik & 0 & $0 \%$ \\
$\quad$ Total & $\mathbf{9 3}$ & $\mathbf{1 0 0 \%}$ \\
\hline
\end{tabular}

Dari tabel 4 diatas dapat dilihat jika mayoritas santri memiliki norma subyektif yang baik untuk telibat aktif dalam Poskestren yaitu sebesar 74,2\%. Dalam hal ini santri juga termasuk dalam usia remaja menuju dewasa, sehingga telah memiliki kematangan sikap untuk melihat dan menyaring lingkungannya sendiri. Dengan tempat dan kondisi yang kondusif untuk mendukung terlibat aktif dalam Poskestren maka akanmenimbulkan norma subyektif yang baik pula. Dari sini dapat disimpulkan bahwa responden memiliki norma subjektif yang baik untuk kondisi dan lingkungannya.

\section{Kontrol Perilaku Responden}

Kontrol perilaku adalah persepsi seseorang tentang mudah atau sulitnya akses serta ada atau tidaknya tenaga ataupun sumber daya yang dibutuhkandalam menampilkan suatu perilaku tertentu. Distribusi responden berdasarkan kontrol perilaku untuk terlibat aktif dalam Poskestren pada santri Pondok Pesantren Al Fitrah dapat dilihat pada tabel 5.

Tabel 5. Distribusi Responden berdasarkan Kontrol Perilaku pada santri
Pondok Pesantren Al Fitrah tahun 2016

\begin{tabular}{lcc}
\hline $\begin{array}{r}\text { Kontrol } \\
\text { Perilaku }\end{array}$ & N & \% \\
\hline Baik & 61 & $65,6 \%$ \\
Cukup Baik & 30 & $32,3 \%$ \\
Kurang Baik & 2 & $2,2 \%$ \\
$\quad$ Total & $\mathbf{9 3}$ & $\mathbf{1 0 0 \%}$ \\
\hline
\end{tabular}

Dari tabel 5 dapat kita lihat jika terdapat $65,6 \%$ responden yang memiliki kontrol perilaku yang baik tentang terlibat aktif dalam Poskestren 65,6\%. Namun ternyata disini beberapa santri masih memiliki kontrol perilaku yang kurang baik untuk terlibat aktif dalam Poskestren.

Kontrol perilaku dapat terbentuk dari mudah atau sulitnya untuk melakukan perilaku tersebut. Mayoritas responden telah mendapatkan kemudahan untuk terlibat dalam Poskestren, namun masih dapat ditemukan juga beberapa responden yang mendaptakan kesulitan untuk terlibat aktif dalam Poskestren.

\section{Niat Responden}

Intensi menurut Ajzen (1985), merupakan komponen dalam diri individu yang mengacu pada keinginan untuk melakukan tingkah laku tertentu. Intensi adalah kesungguhan niat seseorang untuk melakukan perbuatan atau memunculkan suatu perilaku tertentu. niat menghubungkan antara pertimbangan yang mendalam, yang diyakini dan diinginkan oleh seseorang.

Niat untuk terlibat aktif dalam Poskestren di penelitian ini dikategorikan kedalam 2 kategori yaitu Lemah dan Kuat. Distribusi responden berdasarkan niat terlibat aktif dalam Poskestren pada santri Pondok Pesantren Al Fitrah dapat dilihat pada tabel 6 .

Tabel 6. DistribusiResponden berdasarkan Niat pada santri Pondok Pesantren Al Fitrah tahun 2016

\begin{tabular}{lcc}
\hline \multicolumn{1}{c}{ Niat } & N & \% \\
\hline Kuat & 70 & $75,3 \%$ \\
Lemah & 23 & $24,7 \%$
\end{tabular}


Total

$93 \quad 100 \%$

Berdasarkan tabel 6 dapat dilihat jika mayoritas responden memiliki Niat yang kuat untuk terlibat aktif dalam Poskestren. Dapat dikatakan bahwa santri Pondok Pesantren Al Fitrah memiliki keinginan yang kuat untuk terlibat aktif dalam Poskestren. Disini niat bisa dipebgaruhi oleh faktor sikap, norma subyektif, dan kontrol perilaku. Menurut Theory of Planned Behavior, seseorang dapat bertindak berdasarkan intensi atau niatnya hanya jika orang tersebut memiliki kontrol terhadap perilakunya (Ajzen, 2002).

\section{Perilaku Aktif Responden}

Perilaku terlibat aktif dalam Poskestren didapatkan dengan menanyakan persepsi responden tentang jumlah berapa kali terlibat dalam kegiatan Poskestren selama satu minggu. Setelah itu didapatkan data yang kemudian dibagi menjadi dua kategori yaitu cukup dan kurang. Distribusi responden berdasarkan perilaku terlibat aktif dalam kegiatan Poskestren pondok pesantren Al Fitrah dapat dilihat pada tabel 7.

Tabel 7. DistribusiResponden berdasarkan Perilaku pada santPondok Pesantren Al Fitrah tahun 2016

\begin{tabular}{lcc}
\hline \multicolumn{1}{c}{ Perilaku } & N & \% \\
\hline Baik & 69 & $74,2 \%$ \\
Kurang & 24 & $25,8 \%$ \\
\multicolumn{1}{c}{ Total } & $\mathbf{9 3}$ & $\mathbf{1 0 0 \%}$ \\
\hline
\end{tabular}

Dari tabel 7 dapat dilihat jika mayoritas responden memiliki perilaku dalam kategori baik dalam terlibat aktif kegiatan Poskestren. Hal ini menunjukkan bahwa mayoritas responden telah berperan aktif dan ikut terlibat dalam kegiatan Poskestren.

\section{Sikap terhadap Niat terlibat aktif dalam Poskestren}

Mayoritas responden dengan sikap (SK) yang (B) mempunyai niat yang kuat untuk terlibat aktif dalam Poskestren. Namun ada beberapasantri Pondok Pesantren Al Fitrah dengan sikap yang baik mereka mempunyai niat yang lemah untuk terlibat aktif dalam Poskestren.

Tabel 8. Hubungan antara Sikap dengan Niat untuk terlibat aktif dalam Poskestren Tahun 2016

\begin{tabular}{cccccccc}
\hline \multirow{3}{*}{ SK } & \multicolumn{4}{c}{ Niat } & \multicolumn{2}{c}{ Tota } \\
\cline { 2 - 6 } & \multicolumn{2}{c}{ Lemah } & \multicolumn{2}{c}{ Kuat } & \multicolumn{2}{c}{} & \\
\cline { 2 - 6 } & $\mathbf{N}$ & $\mathbf{\%}$ & $\mathbf{n}$ & $\mathbf{\%}$ & $\mathbf{N}$ & $\mathbf{0}$ & - \\
\hline KB & 0 & 0 & 0 & 0 & 0 & 1 & \\
CB & 2 & 40 & 3 & 60 & 5 & 1 & ) \\
B & 21 & 23,9 & 67 & 76,1 & 88 & 1 & ) \\
Total & 23 & 24,7 & 70 & 75,3 & 93 & 11 & ) \\
\hline
\end{tabular}

Dari tabel 8dapat dilihat jika mayoıtas responden dengan sikap yang baik memiliki niat yang kuat untuk terlibat aktif dalam poskestren. Namun responden dengan sikap yang baik ada yang memimiliki niat yang lemah untuk terlibat aktif dalam Poskestren. Hal ini menunjukan bahwa responden dengan sikap yang baik tidak selalu mempunyai niat yang kuat untuk terlibat aktif. Berdasarkan hasil uji statistik untuk mengetahui hubungan antara sikap terhadap perilaku dengan niat terlibat aktif dalam Poskestren menunjukan ada hubungan yaitu $(\mathrm{p}=0,013)$ dengan coefficient contingency sebesar 0,003

\section{Norma Subyektif terhadap Niat}

Disini dapat dilihat jika mayoritas responden dengan norma subyektif yang baik (B) memiliki niat yang kuat untuk terlibat aktif dalam Poskestren. Walaupun begitu ada beberapa responden dengan norma subyektif baik tetapi masih mempunyai niat yang lemah untuk terlibat aktif dalam Poskestren.

Tabel 9. Hubungan antara Norma Subjektif dengan Niat untuk terlibat aktif dalam Poskestren Tahun 2016

\begin{tabular}{|c|c|c|c|c|c|c|}
\hline \multirow{3}{*}{ NS } & \multicolumn{4}{|c|}{ Niat } & \multirow{2}{*}{\multicolumn{2}{|c|}{ Tota }} \\
\hline & \multicolumn{2}{|c|}{ Lemah } & \multicolumn{2}{|c|}{ Kuat } & & \\
\hline & $\mathbf{N}$ & $\%$ & $\mathbf{N}$ & $\%$ & $\mathbf{N}$ & $\overline{0}$ \\
\hline KB & 0 & 0 & 0 & 0 & 0 & 1 \\
\hline CB & 7 & 28 & 18 & 72 & 25 & $11)$ \\
\hline B & 16 & 23,5 & 52 & 76,5 & 68 & $11)$ \\
\hline Total & 23 & 24,7 & 70 & 75,3 & 93 & $11)$ \\
\hline
\end{tabular}


Tabel 5.9 menunjukkan mayoritas responden dengan norma subyektif yang baik memiliki niat yang kuat untuk terlibat aktif dalam Poskestren. Meskipun begitu ada beberapa responden dengan norma subyektif yang baik tetapi masih memiliki niat yang lemah untuk terlibat aktif dalam Poskestren. Berdasarkan hasil uji statistik untuk mengetahui hubungan antara norma subjektif dengan niat terlibat aktif dalam Poskestren, menunjukan tidak ada hubungan yang ada antara norma subjektif dengan niat untuk terlibat dalam Poskestren $(p=0,787)$.

\section{Kontrol Perilaku terhadap Niat Terlibat Aktif dalam Poskestren}

Mayoritas responden dengan kontrol perilaku (KP) yang baik juga memiliki niat yang kuat untuk terlibat aktif dalam Poskestren.Tetapi dapat dilihat jika ada beberapa responden dengan kontrol perilaku baik(B) namun memiliki niat yang lemah untuk terlibat aktif dalam Poskestren. Sebaliknya responden dengan kontrol perilaku yang kurang baik mereka semuanya memiliki niat yang lemah untuk terlibat aktif dalam Poskestren. Hal ini menunjukkan tidak selalu responden dengan kontrol perilaku yang baik memiliki niat yang kuat untuk terlibat aktif dalam Poskestren

Tabel10. Hubungan antara Kontrol perilaku yang dirasakan dengan Niat untuk terlibat aktif dalam Poskestren Tahun 2016

\begin{tabular}{|c|c|c|c|c|c|c|}
\hline \multirow{3}{*}{$\mathbf{K P}$} & \multicolumn{4}{|c|}{ Niat } & \multirow{2}{*}{\multicolumn{2}{|c|}{ Tota }} \\
\hline & \multicolumn{2}{|c|}{ Lemah } & \multicolumn{2}{|c|}{ Kuat } & & \\
\hline & $\mathbf{N}$ & $\%$ & $\mathrm{n}$ & $\%$ & $\mathbf{N}$ & $\overline{\mathbf{0}}$ \\
\hline KB & 2 & 100 & 0 & 0 & 2 & $\overline{11}]$ \\
\hline CB & 10 & 33,3 & 20 & 66,7 & 30 & $11)$ \\
\hline B & 11 & 18 & 50 & 82 & 61 & $11)$ \\
\hline Total & 23 & 24,7 & 70 & 75,3 & 93 & $11)$ \\
\hline
\end{tabular}

Berdasarkan hasil ujichi square antara kontrol perilaku dan niat menunjukkan mayoritas responden dengan kontrol perilaku yang baik juga memiliki niat yang kuat terlibat aktif dalam Poskestren. Tetapi dapat dilihat juga bahwa ada beberapa responden dengan kontrol perilaku yang kuat namun memiliki niat yang lemah untuk terlibat aktif dalam Poskestren. Berdasarkan hasil uji statistik untuk mengetahui hubungan antara kontrol perilaku dengan niat terlibat aktif dalam Poskestren, menunjukan ada hubungan yaitu $(p=0,013)$ dengan coefficient contingency sebesar 0,013

\section{Kontrol perilaku yang dirasakan Terhadap Perilaku terlibat aktif dalam Poskestren}

Hasil tabulasi hubungan antara kontrol perilaku yang dirasakan terhadap perilaku terlibat aktif dalam Poskestren dapat dilihat pada tabel 11

Tabel11.Hubungan antara Kontrol Perilaku dengan Perilaku untuk terlibat aktif dalam Poskestren Tahun 2016

\begin{tabular}{|c|c|c|c|c|c|c|}
\hline \multirow{3}{*}{$\mathbf{K P}$} & \multicolumn{4}{|c|}{ Perilaku } & \multirow{2}{*}{\multicolumn{2}{|c|}{ Tota }} \\
\hline & \multicolumn{2}{|c|}{ Kurang } & \multicolumn{2}{|c|}{ Baik } & & \\
\hline & $\mathbf{n}$ & $\%$ & $\mathbf{n}$ & $\%$ & n & $\underline{\mathbf{0}}$ \\
\hline KB & 2 & 100 & 0 & 0 & 2 & {$[11]$} \\
\hline CB & 8 & 26,7 & 22 & 73,3 & 30 & $11)$ \\
\hline B & 14 & 23 & 47 & 77 & 61 & $11)$ \\
\hline Total & 24 & 25,8 & 69 & 74,2 & 93 & $11]$ \\
\hline
\end{tabular}

Dari tabel 11dapat dilihat jika mayoritas responden dengan kontrol perilaku yang baik juga memiliki perilaku yang baik terlibat aktif dalam Poskestren. Tetapi dapat dilihat juga bahwa ada beberapa responden dengan kontrol perilaku yang kuat namun memiliki perilaku yang kurang untuk terlibat aktif dalam Poskestren.Berdasarkan hasil uji statistik untuk mengetahui hubungan antara kontrol perilaku dengan perilaku terlibat aktif dalam Poskestren, menunjukan ada hubungan yaitu $(p=0,049)$ 
dengan coefficient contingency sebesar 0,049

\section{Niat Terhadap Perilaku terlibat aktif dalam Poskestren}

Mayoritas responden dengan niat yang kuat memilki perilaku yang baik untuk terlibat aktif dalam Poskestren yaitu sebesar $81,4 \%$. Dapat dilihat juga beberapa responden dengan niat yang lemah memiliki perilaku yang baik untuk terlibat aktif dalam Poskestren. Sebaliknya beberapa responden dengan niat yang kuat juga masih ada yang kurang dalam perilaku terlibat aktif dalam Poskestren. Berdasarkan hasil uji statistik untuk mengetahui hubungan antara kontrol perilaku dengan niat terlibat aktif dalam Poskestren, menunjukan ada hubungan yaitu $(\mathrm{p}=0,012)$ dengan coefficient contingency sebesar 0,05

Tabel12. Hubungan antara Norma Subjektif dengan Niat untuk terlibat aktif dalam Poskestren Tahun 2016

\begin{tabular}{lcccccc}
\hline \multirow{2}{*}{ Niat } & \multicolumn{3}{c}{ Perilaku } & \multicolumn{2}{c}{ Total } \\
\cline { 2 - 6 } & \multicolumn{2}{c}{ Kurang } & \multicolumn{2}{c}{ Baik } & \multicolumn{2}{c}{} \\
\cline { 2 - 6 } & $\mathbf{n}$ & $\mathbf{\%}$ & $\mathbf{N}$ & $\mathbf{\%}$ & $\mathbf{N}$ & $\mathbf{\%}$ \\
\hline Lemah & 11 & 47,8 & 12 & 52,2 & 23 & 100 \\
Kuat & 13 & 18,6 & 38 & 81,4 & 70 & 100 \\
Total & 24 & 25,8 & 56 & 74,2 & 93 & 100 \\
\hline
\end{tabular}

Dari analisis dengan uji statistik yang telah dilakukan, maka dapat disimpulkan sebagai berikut:

Tabel13.Hasil uji statistik hubungan antara sikap terhadap perilaku, norma subjektif dan kontrol perilaku yang dirasakan dengan niat berperan aktif dalam Poskestren

\begin{tabular}{lc}
\hline Variabel & P \\
\hline Sikap & 0,013 \\
Norma Subjektif & 0,787 \\
Kontrol Perilaku & 0,013
\end{tabular}

Tabel14.Hasil uji statistik hubungan antara kontrol perilaku yang dirasakan dan niat terlibat aktif dengan perilaku aktif dalam Poskestren

\begin{tabular}{lc}
\hline Variabel & P \\
\hline Kontrol Perilaku & 0,049 \\
Niat terlibat & 0,012 \\
aktif &
\end{tabular}

\section{Karakteristik Santri Pondok Pesantren Al Fitrah Surabaya}

Sesuai dengan hasil penelitian, karakteristik santri putra yang dijadikan sebagai responden berdasarkan kategori umur mayoritas santri putra Pondok Pesantren Al Fitrah berkisar antara 16-20 tahun dengan jumlah terbanyak pada umur 19 tahun yaitu sebesar 41,9 \% dari responden santri pondok pesantren Al Fitrah Surabaya. Usia 16-20 tahun merupakan kriteria remaja akhir sebelum memasuki usia dewasa. Untuk remaja akhir atau late adolescence ditandai dengan pertumbuhan biologis yang sudah melambat, tetapi masih berlangsung. Emosi, minat, konsentrasi, dan cara berpikir remaja akhir mulai stabil. Kemampuan untuk menyelesaikan masalah sudah mulai meningkat. Pada tahap ini, remaja lebih berkonsentrasi pada rencana yang akan datang serta bagaimana meningkatkan pergaulan (Poltekkes Depkes Jakarta I, 2010).

Pondok Pesantren Al Fitrah adalah salah satu intitusi pendidikan islam terkemuka yang berada di Kota Surabaya. Selain untuk menunjang kegiatan pembelajaran baik itu ilmu umum maupun ilmu agama, setiap hari santri juga di didik untuk dapat hidup mandiri, terampil dan ulet agar dapat menjadi pembelajaran untuk menjadi pribadi yang baik lagi dan memilki akhlaqul karimah.

Dalam penelitian ini ada dua variabel yang dijadikan sebagai Background Factor dalam perilaku terlibat aktif dalam Poskestren. Kedua variabel tersebut adalah umur dan pengetahuan responden terhadap perilaku terlibat aktif dalam Poskestren. Kedua variabel ini nantinya akan disajikan dalam bentuk tabel 
dan diinformasikan dalam persentase untuk mengetahui umur dan tingkat pengetahuan dari responden . Dari 93 responden dalam penelitian ini didapatkan jika kesemuanya adalah santri putra yang mana mereka adalah santri mukim yang tinggal di asrama putra Pondok Pesantren Al Fitrah. Asrama putra yang mereka tempati adalah bangunan gedung berlantai 3 dengan 20 kamar yang ada di dalamnya. Setiap kamar berisikan santri mukim yang tercampur dari berbagai kelas dan umur.

Pengetahuan santri putra Pondok Pesantren Al Fitrah mengenai konsumsi buah dan sayur mayoritas dalam kategori baik yakni sebesar 60,2\%. Dari hasil penelitian tidak ada santri Pondok Pesantren Al Fitrah yang masuk dalam kategori pengetahuan yang kurang tentang pentingnya terlibat aktif dalam Poskestren

\section{Sikap Terlibat Aktif dalam Poskestren}

Berlandaskan Theory of Planned Behavior yang dinyatakan oleh Ajzen (2005), sikap terhadap perilaku ditentukan oleh keyakinan terhadap konsekuensiyang timbul dari suatu perilaku yang ditampilkan. Ajzen mengungkapkan bahwa belief dapat diungkapkan dengan cara menghubungkan suatu perilaku dengan berbagai manfaat atau kerugian yang mungkin diperoleh apabila kita melakukan atau tidak melakukan perilaku itu.

Dalam penelitian ini sikap diukur melalui manfaat terlibat aktif dalam Poskestren bagi responden. Keyakinan ini yang nantinya akan dijadikan dugaan terhadap niat untuk terlibat aktif dalam Poskestren. Hasil penelitian menunjukkan bahwa sebanyak 94,6 \% responden memiliki sikap yang baik terkait perilaku terlibat aktif dalam Poskestren. Sikap yang baik ini menunjukkan bahwa santri putra Pondok Pesantren Al Fitrah memiliki sikap yang positif dalam mendukung terbentuknya niat untuk terlibat aktif dalam Poskestren.

\section{Norma SubyektifTerlibat Aktif dalam Poskestren}

Norma subyektif merupakan persepsi seseorang terhadap tekanan sosial yang ada untuk menampilkan atau tidak menampilkan suatu perilaku dan kesediaan untuk mematuhi tuntutan dari tokoh yang penting menurut dirinya (Ajzen, 2005). Dalam penelitian ini tokoh yang dianggap penting adalah orang tua, teman dan kyai serta ustadz yang ada di Pondok Pesantren Al Fitrah. Ketiga tokoh tersebut memberikan kontribusi dalam mempengaruhi niat santri untuk terlibat aktif di Poskestren.

Beradasarkan hasil penelitian mayoritas santri Pondok Pesantren Al Fitrah memiliki norma subyektif yang sangat baik $(73,1 \%)$. Banyaknya responden yang memiliki norma subyektif yang baik tentunya tidak hanya dipengaruhi oleh tuntutan tokoh penting namun berkaitan juga dengan keinginan dan motivasi responden untuk memenuhi tuntutan tersebut.

\section{Kontrol Perilaku Terlibat Aktif dalam Poskestren}

Kontrol perilaku berdasarkan Theory of Planned Behavior (Ajzen, 2005) diasumsikan sebagai suatu keyakinan mengenai ada atau tidaknya berbagai faktor yang memfasilitasi atau menghalangi dalam menampilkan suatuperilaku tertentu. Keyakinan ini dapat didasari oleh pengalaman masa lalu, namun bisa juga dipengaruhi oleh informasi yang didapatkan responden dari orang lain. Selain itu juga dipengaruhi oleh faktor lain yang meningkatkan atau menurunkan persepsimengenai kesulitan untuk menampilkan suatu perilaku tertentu.

Dalam penelitian ini faktor yang digunakan sebagai tolak ukur kemudahanatau kesulitan menampilkan perilaku adalah kemampuan santri untuk menjangkau, kemudahan akses, dan dampak kedepannya dalam memunculkan perilaku. Dari hasil penelitian, mayoritas respondendapat dikatakan memiliki kontrol perilaku yang baik yaitu sebesar $65,6 \%$. Hal ini menunjukkan bahwa mayoritas 
responden merasa tidak sulit untuk terlibat aktif dalam Poskestren

\section{Niat Terlibat Aktif dalam Poskestren}

Niat atau intensi menurut Ajzen (1985), merupakan komponen dalam diri individu yang mengacu pada keinginan untuk melakukan tingkah laku tertentu. Intensi adalah kesungguhan niat seseorang untuk melakukan perbuatan atau memunculkan suatu perilaku tertentu. Intensi menghubungkan antara pertimbangan yang mendalam, yang diyakini dan diinginkan oleh seseorang dengan tindakan tertentu.

Dalam penelitian niat diukur berdasarkan keinginannya untuk melakukan perilaku disaat ini dan yang akan datang. Dalam hal ini mayoritas responden telah memiliki niat yang kuat untuk terlibat aktif dalam Poskestren. Hal ini menunjukkan mayoritas santri telah memiliki niat yang positif untukmemunculkan perilaku terlibat aktif dalam Poskestren

\section{Hubungan Sikap, Norma Subyektif, Kontrol Perilaku terhadap Niat dan Perilaku Terlibat Aktif dalam Poskestren}

Hasil analisis bivariat dengan menggunakan chi square menunjuka bahwa ada hubungan antara sikap terhadap perilaku santri terhadap niat untuk berperan aktif dalam Poskestren di Pondok Pesantren Al Fitrah yaitu $(\mathrm{p}=0,013)$ dengan coefficient contingency sebesar 0,003 .

Sikap terhadap perilaku santri untuk aktif terlibat dalam Poskestren tentu sangat berhubungan dengan kesungguhan niat yang dimilki, hal ini jug sesuai dengan teori planned behavior yang dikemukakan oleh Ajzen jika sikap terhadap perilaku memilki pengaruh terhadap niat seseorang untuk mengerjakan suatu hal tersebut, Ajzen juga mengatakn jika belief yang ada pada orang itulah yang membentuk sikap terhadap perilaku dari individu itu sendiri hingga akhirnya menimbulkan niat (Ajzen, 2005), Sesuai dengan Theory of Planned Behavior yang ditulis oleh Ajzen (2005) yang menyebutkan bawa sikap terhadap perilaku merupakan salah satur faktor pembentuk niat.

Dalam penelitian ini norma subyektif tidak menunjukkan hubungan yang signifikan terhadap niat untuk terlibat aktif dalam Poskestren $(\mathrm{p}=0,787)$. Hal ini tidak sesuai dengan Theory of Planned Behavior (Azjen, 2005) bahwa norma subyektif merupakan variabel yang mempengaruhi niat. Norma subyektif seseorang dipengaruhi oleh sejauh mana orang yang dianggap penting (Referent) akan mendukung atau melarang perilaku tersebut.

Dapat disimpulkan bahwa pengaruh referent belum tentu bisa memberikan pengaruh terhadap niat responden untuk terlibat aktif dalam Poskestren. hasil penelitian ini juga tidak mendukung hasil penelitian yang telah dilakukan oleh Lin dan Lee (2004) yang menunjukkan bahwa terdapat hubungan positif antara norma subyektif terhadap niat dalam hal berbagi pengetahuan. Tidak adanya hubungan antara norma subjektif dan niat santri untuk terlibat aktif dalam Poskestren ini juga bisa dikaitkan dengan apa yang diutarakan Notoatmojo (2003) jika respon pada setiap orang tidak sama karena memiliki beberapa faktor yang mempengaruhi meliputi pengalaman pribadi, kebudayaan, orang yang dianggap penting dan media masa. Dimana faktor tersebut dapat memberikan stimulus yang sama akan tetapi belum tentu memunculkan sikap yang sama sehingga perilaku yang ditampilkan juga bisa tidak sama, sehingga norma subjektif tidak selalu berpengaruh terhadap niat dan perilaku yang ditampilkan, karena sikap memiliki komponen yang kompleks menyangkut kepribadian personal, lingkungan, sosial ekonomi, ras, jenis kelamin, pendidikan dan keturunan. .

Dalam penelitian ini Kontrol perilaku terlibat aktifnya santri dalam Poskestren berhubungan positif dengan kesungguhan niat yang dimilki $(\mathrm{p}=0,013)$, hal ini juga sesuai dengan teori planned behavior yang dikemukakan oleh Ajzen jika kontrol perilaku memilki pengaruh terhadap niat seseorang untuk mengerjakan suatu hal 
tersebut, hasil penelitian ini juga sesuai dan mendukung dari penelitian Dwi dan Andri (2010) tentang aplikasi Theory Planned Behavior dalam taat wajib pajak.

Dalam Theory of Planned Behavior menyebutkan bahwa selain niat, kontrol perilaku juga bisa dijadikan faktor secara langsung yang mempengaruhi perilaku. Dalam penelitian ini menunjukkan bahwa kontrol perilaku berhubungan positif terhadap perilaku terlibat aktif santri dalam Poskestren $(p=0,049)$. Hal ini diliat dari nilai signifikansi kontrol perilaku yang lebih kecil dari 0,05. Dapat disimpulkan bahwa kemudahan dan kesulitan untuk menampilkan perilaku bagi responden dapat menunjukkan perilakunya sesuai dengan yang diungkapkan oleh Ajzen (2005)

Dalam penelitian ini juga dapat dilihat jika niat berhubungan positif terhadap perilaku santri untuk terlibat aktif dalam Poskestren $(p=0,012)$. Sesuai dengan Ajzen (2005) bahwa niat memang berperan secara langsung dalam pembentukan perilaku.

\section{SIMPULAN DAN SARAN}

Responden adalah santri Pondok Pesantren Al Fitrah dengan jumlah 93 responden, usia mereka berkisar antara 1620 tahun. Hampir kesemua responden telah mempunyai sikap dan norma subyektif yang baik untukterlibat aktif dalam Poskestren. Namun masih terdapat beberapa responden dengan kontrol perilaku yang kurang.

Dari hasil penelitian yang telah dilakukan dapat disimpulkan jika variabel sikap dan kontrol perilaku memilki hubungan positif terhadap niat untuk terlibat aktif dalam Poskestren. Sedangkan, Variable norma subyektif memilki hubungan negatif terhadap niat untuk terlibat aktif dalam Poskestren. Dalam penelitian ini juga dapat dilihat jika kontrol perilaku dan niat juga memiliki hubungan positif yang langsung dengan perilaku aktif dalam Poskestren

Bagi Santri Pondok Pesantren Al Fitrahdengan melihat adanya hubungan niat, sikap dan kontrol perilaku terhadap perilaku terlibat aktif dalam Poskestren, maka perlu adanya upaya untuk meningkatkan niat santri dengan juga memperbaiki norma subjektif yang ada karena melihat tidak adanya hubungan antara naorma subjektif dengan niat santri untuk terlibat aktif dalam Poskestren. Perlu adanya media promosi kesehatan di lingkungan asrama Pondok Pesantren Al Fitrah untuk menambah informasi kepada santri.Terkait kontrol perilaku reponden yang menunjukkan masih adanya beberapa responden dengan kontol perilaku yang kurang baik bisa diatasi dengan memudahkan akses dan dengan sosialisasi yang lebih baik lagi

\section{DAFTAR PUSTAKA}

Ajzen, I. 1985. From intentions to actions: A theory of planned behavior. In J. Kuhl \& J. Beckman (Eds.), Actioncontrol: From cognition to behavior (pp. 11- 39). Germany: Springer. 2005. Attitudes, Personality, and Behavior (2nd. Edition). England: Open University Press / McGraw- Hill.

Ajzen, Icek dan Fishbein, Martin, 2005. Theory -based Behavior Change Interventions: Comments on Hobbis and Sutton. Journal of Health Psychology Vol. 10, No. 1, 27-31

Amin, Haedari, 2004. Masa Depan Pesantren Dalam Tantangan Modernitas dan Tantangan Komplesitas Global. Jakarta: IRD Press.

Glanz, K., Rimer, B. K. \& Viswanath, K., 2008. Health Behavior and Health Education. $\quad 4^{\text {th }}$ editon San Francisco: Jossey Bass.

Menteri Kesehatan Republik Indonesia., 2013. Peraturan Menteri Kesehatan Republik Indonesia Nomor 1 Tahun 2013 Tentang Pedoman Penyelenggaraan Dan Pembinaan Poskestren. Jakarta: Menteri Kesehatan Republik Indonesia. 
Menteri Kesehatan Republik Indonesia., 2006. Keputusan Menteri Kesehatan Republik Indonesia Nomor 867 Tahun 2006 Tentang Pedoman Penyelenggaraan Dan Pembinaan Poskestren. Jakarta: Menteri Kesehatan Republik Indonesia.

Notoadmodjo, S., 2005. PROMOSI KESEHATAN Teori dan Perilaku. Jakarta: PT RINEKA CIPTA.

Notoadmodjo,S., 1993. Metode Penelitian Kesehatan. Jakarta: Rineka Cipta

Menteri Kesehatan Republik Indonesia., 2006. Keputusan Menteri Kesehatan Republik Indonesia Nomor 867 Tahun 2006 Tentang Pedoman Penyelenggaraan Dan Pembinaan Poskestren. Jakarta: Menteri Kesehatan Republik Indonesia.

Notoadmodjo,S. 2004. Pendidikan dan Perilaku Kesehatan. Jakarta: Rineka Cipta. 2007. Promosi Kesehatan: Teori dan Perilaku. Jakarta: Rineka Cipta

Poltekkes Depkes Jakarta I. 2010. Kesehatan Remaja: Problem dan Solusinya. Jakarta: Salemba Medika 
JURNAL ILMIAH KESEHATAN MEDIAHUSADA ｜ＶOLUME 05/NOMOR 02/OKTOBER 2016 